\title{
STUDENTS' PERCEPTION TOWARDS THE USE OF GOOGLE CLASSROOM IN WRITING SUBJECT
}

\author{
Eva Fitriani Syarifah \\ English Language Education Study Program, Faculty of Teacher Training and Education \\ Universitas Majalengka \\ evafitrianisyarifah@unma.ac.id
}

\begin{abstract}
Google Classroom is one of features from Google that mostly used by the educators recently. It helps them to submit and organize the students' assignments. The main purpose of this study is to investigate students' perception towards the use of Google Classroom in writing subject. The study is carried out through a qualitative research design. The study involved the students of higher education who have used Google Classroom in writing subject for at least one semester. The data obtained through questionnaire and interview. The data obtained were analyzed by using thematic analysis. Finding revealed that students perceive it as a tool that helps them to submit the assignment easily. They assumed that it assist them in managing the assignment better. Thus, it can be concluded that Google Classroom is useful for both lecturer and student in writing subject.
\end{abstract}

Keywords: Google Classroom, writing, technology integration, technology in ELT

\section{INTRODUCTION}

The integration of technology in classroom is a new trend in education. Hwang et.al (2015) mention that integration of technology in the classroom enables students to achieve learning objectives. It is because technology facilitates students' engagement (Northey, Bucic, Chylinski, \& Govind, 2015). Technologies along with the traditional classroom setup are possible to use in order to enhance the learning environment for the students. Therefore, the classroom can be more enjoyable for students.

The impact of technology also can be seen from the use of technology in teaching and learning process that include in university level. Both of lecturers and students have already got the advantage of technology to support their activities. They use computer and mobile phones to help them in solving their problems or minimizing the difficulties whether it is supported with internet connection or not. Most of the lecturers use technology to get easiness in collecting students' assignments. Commonly, the lecturers ask the students to submit their assignments by sending via e-mail. This technique is better rather than asks the students to collect their assignment directly in form of paper task, because it saves times in collecting and checking the assignments one by one. However, this technique still has weaknesses for some reasons. First, the students cannot have discussion with the lecturer about their assignments. They only can send their assignment without knowing the further feedback. Second, the students do not know their scores. It means that it is lack transparency. Third, students may send their assignment into incorrect e-mail address. Absolutely, the assignment will not be sent to the lecturer's e-mail if the students do not realize their mistake.

Thus, to solve the weaknesses, lecturers need to get other techniques in collecting the students' assignments. Actually, the development of technology has given easiness and support in education environment where there are many mobile based applications designed that can be used as a tool in collecting students' assignments. One of the application is Google Classroom which is can be used to support teaching and learning process. Google Classroom is an application that have been developed by Google Inc. for educational space intended to find a way out the difficulty of creating, delivering, and classifying any paperless assignments. This application can be used on smartphone or computer where both lecturer and students can download it freely and $\log$ in easily. The lecturer only need to create a class and share the class code to the students to let them to join with the class created. Through this application, students can submit their assignment easily, revise their assignment, and also check their scores given by the lecturer. 
Perez (2015) mentions that through Google Classroom, assignment is created and Gmail is used to provide classroom communication which makes teachers easier to announce and ask questions to students in classes. On the other hand, Pappas (2015) as cited in Sepyanda (2018) asserts that not all learning courses are suitable using Google Classroom. It has difficult account management, limited integration options, no automated updates, difficult learner sharing, editing problems, and many more. However, there are some studies that have been conducted and they were related to the use of Google classroom in English language learning (Espinosa, Estira, \& Ventayen, 2017; Machado \& Chung, 2015;; Shaharanee, Jamil, \& Rodzi, 2016). In addition, the study that focuses on students' perception towards the use of Google Classroom is still limited. Investigating this focus is important since the students are the users of application. Thus, this study is carried out to investigate students' perception towards the use of Google Classroom specifically in writing subject.The educational technology, at the moment, is not transformative alone, student learning can improve only through a teacher; therefore, it is absolutely essential that teachers' acceptance of technology is present. Azhar (2018) has mentioned two elements in providing an environment for technology integration. First, teachers need to place technology into the hands of students carefully by selecting the right mediums. Second, technological tools should be constantly evolving to enhance problem-solving, innovation, decisionmaking, and teamwork.

Teachers can now use a number of educational technologies, along with the traditional classroom setup, to enhance the learning environment for the students. The application is free to use for teachers and students which makes it an ideal fit for developing countries, where the budgets are limited. It can act as a learning management system in schools, colleges, and higher education institutes. Teachers can effectively utilize classroom time using Google Classroom.

Google classroom was firstly launched in 2014. It is a tool that facilitates collaboration between students and teachers. Google Classroom can be a tool that makes learners become active participants. Iftakhar (2016) argues that teachers can create active lessons which are student-centered, collaborative, and unforgettable just through Google Classroom. This is because it provides easy-to-use learning features with students of all categories able to cooperate. It makes teachers simply create groups to share assignments and announcements. In addition, teacher can also create and distribute assignments for students in an online classroom for free (Bolkan, 2015).

Google Classroom is helpful to all of learner categories and including adult learners. It also has some benefits such as paperless, can be accessed anywhere and everywhere as long as there is internet connection and from any devices. In addition, it also can become a mean to communicate between teachers and students, to give feedback to students, and personalized learning. It has a learning feature that makes teachers create and handle assignments actively and also provide feedback to students. Google Classroom makes it easier for teachers to handle students work. It is really beneficial for both teachers and students, because it is easy and simple to use.

There are several steps to use Google Classroom First, we may download application and sign in. Then, as teacher we may create class or as students we may join the class. After that, Teacher can add a class name and add the details about the class, such as, description and instructions for students in the "about" tab, and also Google Drive folder for classroom materials and can attach outline course and lesson plan. Finally, the class is ready and students can freely join if they have institutional Google accounts and they should find class code in the "stream" tab.

Working with Google Classroom, teacher may create announcement. Teacher can give announcements about the update of the class in this section. They can attach files and class materials as well. In addition, they may also create assignment. This is the most substantial 
feature in Google Classroom. Teacher can upload assignments for student within due time to submit. Student also can download materials that have been uploaded by teacher to finish their task. Next, teacher and students can create question. In this section, student can create question to be discussed with teacher or other students if allowed by teacher. Fourth, re-use post. Important post can be used by teacher in this section, such as, announcement, assignment, and question.

Google Classroom has copious facilities which are beneficial for its users. A few of them are user friendly, cost free, cell phone friendly, and time saving. Using Google Classroom is really easy. In line with Iftakhar (2016) who mentions that Google Classroom's design purposefully simplifies the instructional interface and options used for delivering and tracking assignments; communication with the entire course or individuals is also simplified through announcements, email, and push notifications. Using Google Classroom does not need any cost. It is free for anyone. Although users have institutional Google Account, they still can use it for free. Anyone can use Google classroom on any mobile device as long as there is internet connection. Iftakhar (2016) also states that mobile access to learning materials that are attractive and easy to interact with is critical in today's web connected learning environments. By using Google Classroom both teacher and student can save their time. Iftakhar (2016) adds that it integrates other Google apps, like, Docs, Slides, Drive and Spreadsheets. Nevertheless, the whole process of administering assignments, grading, formative assessment, and feedback is simplified and streamlined.

However, Google Classroom also has some limitations. Pappas (2015) as cited in Sepyanda (2018) mentions that Google Classroom is limited integration option, too googlish, no automated updates, difficult learner sharing and editing problems. It is difficult for teacher to manage teaching materials and to set deadline for assignments because Google Classroom is not synchronized with Google Calendar or any other calendar. Some of Google Classrooms' buttons are only familiar for Google users. It can make new user feeling confused or needing more time to deal with it.

\section{METHOD}

This research employs qualitative exploratory research design. Purposive sampling technique was used. Participants for the study were selected from the students that were using Google Classroom for at least one semester. There were seven students that selected as the participants. All the participants were higher education students. They were at the second semester. At the moment, they took writing subject and used Google Classroom during the semester. To investigate students' perception towards the use of Google Classroom in writing subject, open ended questionnaire and interviews were selected to obtain the data. An open ended questionnaire was distributed to investigate the students' perception towards familiarity, advantages and disadvantages of Google Classroom. The bases of a set of questions were devised from the literature review and past studies. Then, to confirm unclear information or data obtain through questionnaire, semi structure interviews were conducted. To protect the confidentiality of the participants, codes were assigned to participants at the time of transcription of interviews. During the process of interview, the students' judgments and responds were video recorded. The data gathered were transcribed and selected to draw a theme. Field notes was also used Then, thematic analysis was conducted to find the result of the research and interpret the data.

\section{FINDINGS AND DISCUSSION}

Based on the data obtained through the questionnaires and interviews, the students give positive perception towards the use of Google Classroom in writing subject. The data gathered were related to students' familiarity and knowledge about Google Classroom, its advantages and disadvantages. 
The data obtained from questionnaire and interviews indicate that the students are familiar with Google Classroom. In addition, they also have a good understanding about Google Classroom. This is because they have used Google Classroom for one semester so they know how to use it and they know each feature provided in Google Classroom. The following are data related to students' (S) familiarity and knowledge about Google Classroom the which taken from the interview result.

Google classroom is application, free. We can use it as online class. It has many features such as for submit assignment, learning, and others. (S2)

I have used Google Classroom for about one semester. There are some features in Google Classroom such as for forum for discussion, for knowing the learning materials, submit assignment, and others. (S1)

Google Classroom is an application, it is free. I use it in some courses such as writing. I use it for submiting assignment, downloading learning materials, asking for instruction or materials to lecturer and friends. (S5)

Google Classroom is a good application for Teacher and Students that support them in communicating anytime without face to face. As far as I used the application,I mostly used the features for submitting assignments, downloading learning materials, and reading the instruction.(S3)

Related to the result of data analysis, the students mentioned that they used Google Classroom for some reasons. They mostly use it for submitting assignments. Then, they also use stream feature to discuss with lecturer and friends. Moreover, they can have materials that are posted by the lecturers. Through Google Classroom, the students got more feedback from lecturers and peer. This is supported by Sharanee et.al (2016) who argues that Google Classroom support active learning environment.

The students perceive that Google Classroom is really helpful. It gives many advantages for them. First, ease of access. The students enable to access course materials, send and receive assignment and submit assignment. They also mentioned that the quality of learning activity was excellent. Google classroom helps students to submit assignment on time. The feedback provided by the lecturer is useful. The grading system in Google classroom helps in monitoring students' performance and understanding the current topic discussed. The subject objective, assessment and content were consistent with the aid of Google Classroom. Moreover, students felt comfortable conversing through this application because lecturer helped participants engaged discussion; they felt comfortable interacting with other participants. Below are data taken from the interview which indicate the advantages of using google classrooom.

I like using google classroom because it is easy. (S1)

Google classroom gives notification of assigment deadline. I can check the feedback easily. (S3)

I can discuss the material or anything via google classroom. It helps me a lot. (S6)

In my opinion the features are complete package. I can submit assignment, disscuss, see learning materials, and get instructions clearly. (S2)

Based on the results of the interview, all of the students were satisfied after using Google Classroom in writing subject. They mentioned that Google Classroom can be as learning initiative and motivation booster. These are in line with Azhar (2018), and Bolkan (2015) who mentioned that Google Classroom give more benefits for the users. Talking about diadvantages, after using Google Classroom in their writing subject for one semester, the students almost have no difficulties. All of the participants only mentioned that the problem was only internet connection. Sometimes, the students have no internet connection so they can access Google Classroom. This is in line with Espinosa et al (2017) and Pappas (2015) as cited in Sepyanda (2018) who mention that Google Classroom can be accessed anytime and 
anywhere as long as we have internet connection. Thus, based on the students perception, google classroom has more advantages than disadvantages. During one semester they use google classroom, they mention that google classroom is really helpful for them to complete the assignment of writing subject. In addition, they can read instruction carefully in the task description and asking more information if they do not understand about the assignment.

\section{CONCLUSION}

The results of the study indicate that Google Classroom is useful. The students mentioned that Google Classroom help them in managing their writing assignment. In addition, the features that are provided in Google Classroom can be use easily by the students. Moreover, the students can access Google Classroom anytime, anywhere, as long as they have internet access. Thus, Google Classroom can be one of alternative medium that can be used by the teacher in teaching writing. Specifically, to manage the students' assignment so it can be paperless and easy to deliver feedback.

\section{REFERENCES}

Azhar, K.A. (2018). Effectiveness of Google Classroom: Teachers' Perceptions. Prizren Social Science Journal, 2(2), 52-66.

Bolkan, S. (2015). Intellectually Stimulating Students' Intrinsic Motivation: The Mediating Influence of Affective Learning and Student Engagement. Communication Reports, 28(2), 80-91. https://doi.org/10.1080/08934215.2014.962752

Hwang, G.-J., Lai, C.-L., \& Wang, S.-Y. (2015). Seamless flipped learning: a mobile technology - enhanced flipped classroom with effective learning strategies. Journal of Computers in Education, 2(4), 449-473. https://doi.org/10.1007/s40692015-0043-0.

Northey, G., Bucic, T., Chylinski, M., \& Govind, R. (2015). Increasing Student Engagement Using Asynchronous Learning. Journal of Marketing Education, 37(3), 171-180. https://doi.org/10.1177/0273475315589814

Pappas, C. (2015, August 20). Google Classroom Review: Pros And Cons Of Using Google Classroom In eLearning. Retrieved from elearningindustry: https://elearningindustry.com/google-classroom-review-pros-and-cons-of-usinggoogle-classroom-in-elearning

Espinosa, N., Estira, K. L., \& Ventayen, R. J. M. (2017). Usability Evaluation of Google Classroom: Basis for the Adaptation of GSuite E-Learning Platform. Asia Pacific Journal of Education, Arts, and Science, 5(1).

Machado, L. J., \& Chung, C.-J. (2015). Integrating Technology: The Principals' Role and Effect. International Education Studies, 8(5), 43. https://doi.org/10.5539/ies.v8n5p43

Martínez-Monés, A., Reffay, C., Torío, J. H., \& Cristóbal, J. A. M. (2017). Learning Analytics with Google Classroom: Exploring the Possibilities. In Proceedings of the 5th International Conference on Technological Ecosystems for Enhancing Multiculturality (p. 47:1-47:6). New York, NY, USA: ACM. https://doi.org/10.1145/3144826.3145397

Iftakhar, S. (2016). Google Classroom: What Works and How? Journal of Education and Social Sciences, Vol. 3, 7.

Sepyanda, M. (2018). Students' Attitude toward the Use of Google Classroom on Translation Subject in English Department of Fkip UMMY Solok. English Language Teaching and Research, Vol 2, 1.

Shaharanee, I. N. M., Jamil, J. M., \& Rodzi, S. S. M. (2016). Google classroom as a tool for active learning. AIP Conference Proceedings, 1761(1), 020069. https://doi.org/10.1063/1.4960909

Spring, K. J., Graham, C. R., \& Hadlock, C. A. (2016). The current landscape of international blended learning. International Journal of Technology Enhanced Learning, 8(1), 84-102. https://doi.org/10.1504/IJTEL.2016.075961 